\title{
The International Bureau of Education: A Precursor of the Unesco and the Factory of its Pedagogical Guidelines? (1934-1968)
}

\author{
Rita Hofstetter \\ University of Geneva \\ Bernard Schneuwly \\ University of Geneva
}

\begin{abstract}
Our article contributes to tracing the sociogenesis of "educational internationalism" as promoted by the International Bureau of Education (IBE) when it became an intergovernmental organization in 1929, cooperating with Unesco since 1947, before being fully integrated in 1969. The IBE can be considered as one of the precursors of Unesco, a kind of factory of its pedagogical guidelines: it develops a modus operandi for producing, through a comparative approach, in as objective and neutral a manner as possible, knowledge concerning the progress of education in the world and recommendations forming a charter of world aspirations in education. These matters are discussed in International Conferences on Public Education (ICPE). With the birth of Unesco, the IBE negotiates a status of autonomy and collaboration, continuing its technical work based on comparative education. The problems studied, defined by both institutions together, relate to three crucial fields: access to education, curriculum, teacher education. The IBE's approach is far from being free of tensions: in the results themselves of its work and between the countries participating in IBE's inquiries and the ICPEs.
\end{abstract}

ISSN 2560-8371

DOI: 10.24908/encounters.v21i0.14212

(C) Encounters in Theory and History of Education | 24 
Keywords: International Bureau of Education (IBE), Unesco, educational internationalism, Piaget, International Conferences of Public Education

\section{Le Bureau international de l'éducation : Un précurseur de l'Unesco et l'usine de ses lignes directrices? (1934-1968)}

\section{Résumé}

Notre article contribue à retracer la sociogenèse de « l'internationalisme éducatif » tel que promu par le Bureau international d'éducation (BIE) lorsqu'il est devenu une organisation intergouvernementale en 1929, coopérant avec l'Unesco depuis 1947, avant d'être pleinement intégré en 1969. Le BIE peut être considéré comme l'un des précurseurs de l'Unesco, une sorte d'usine des orientations pédagogiques de cette dernière : il développe un mode opératoire pour produire, par une approche comparative, de manière aussi objective et neutre que possible, des connaissances concernant le progrès de l'éducation dans le monde et des recommandations formant une charte des aspirations mondiales en matière d'éducation. Ces questions sont discutées dans le cadre des Conférences internationales d'instruction public (CIIP). Avec la naissance de l'Unesco, le BIE négocie un statut d'autonomie et de collaboration, en poursuivant son travail technique basé sur l'éducation comparée. Les problèmes étudiés, définis par les deux institutions ensemble, concernent trois domaines cruciaux : l'accès à l'éducation, le curriculum, la formation des enseignants. L'approche du BIE est loin d'être exempte de tensions : dans les résultats mêmes de ses travaux et entre les pays participant aux enquêtes du BIE et les CIPE.

Mots-clés: Bureau international de l'éducation (BIE), Unesco, internationalisme éducatif, Piaget, Conférences internationales d'instruction publique

\section{Oficina Internacional Educación: Precursora de la Unesco y la fábrica de sus guías pedagógicas? 1934-1968)}

\section{Resumen}

Este artículo contribuye a rastrear la sociogénesis del "internacionalismo educativo" promovido por el International Oficina Internacional de Educación (OIE) cuando se convirtió en una organización intergubernamental en 1929, cooperando con la UNESCO desde 1947, antes de integrarse plenamente en 1969. La IBE puede considerarse como uno de los precursores de la UNESCO, una especie de factoría de sus orientaciones pedagógicas: desarrollando un modus operandi para producir, a 
través de un enfoque comparativo, de la manera más objetiva y neutral posible, el conocimiento sobre el progreso de la educación en el mundo y recomendaciones que forman una carta de aspiraciones mundiales en educación. Estos temas se discutieron en las International Conferences on Public Education (ICPE). Con el nacimiento de la UNESCO, la IBE negocia un estado de autonomía y colaboración, continuando su labor técnica basada en la educación comparada. Los problemas estudiados, definidos por ambas instituciones en conjunto, se relacionan con tres campos cruciales: acceso a la educación, currículo y formación del profesorado. El enfoque de la IBE no está libre de tensiones, los cuales se visibilizan en los resultados mismos de su trabajo y en las relaciones entre los países que participan en las investigaciones de la OIE y los ICPE.

Palabras clave: Oficina Internacional de Educación (OIE), Unesco, internacionalismo educativo, Piaget, Conferencias internacionales de Educación Pública
At first, I hesitated between several solutions. It was only when I saw several members of Unesco conceive of the Unesco-IBE marriage a little like that of the praying mantis, after which the wife absorbs the husband, that I fought for the autonomy of the Bureau. (Piaget, Minutes of the 25th meeting of IBE Council, July 11, 1959 p. 7; B49, A-BIE).

This is how the Director of the International Bureau of Education (IBE), the psychologist Jean Piaget (1896-1980), justified the position taken in 1946 when the IBE and Unesco negotiated a collaboration agreement. For Piaget, it was a "marriage of convenience" to preserve the existence and independence of the IBE. The IBE's Deputy Director, Pedro Rosselló (1897-1970), resorted to another equally powerful family metaphor during negotiations:

I enclose herewith the draft provisional agreement which we have obtained after a very hard struggle with the representatives of Unesco. [...] We are attempting a very difficult operation that of seeing the IBE, to whom we wish to confer all the honors of Unesco's "father", become his little brother. (Letter of Rosselló to Bovet, January 3, 1947, B160, A-BIE).

Virtually unknown today, did the IBE go from being Unesco's father to its little brother, or was it the husband swallowed up by his wife in the image of the praying mantis? Following a wide-ranging survey based on an analysis of the voluminous available archival resources, ${ }^{1}$ we adopt a more nuanced stance, advancing the thesis that the IBE could indeed appear as one of the forgotten precursors of Unesco ${ }^{2}$ : as the first instance of intergovernmental co-operation in education, the IBE is in a certain sense a factory producing educational guidelines that are later on taken up and relayed by Unesco. 
We propose to demonstrate this by retracing the sociogenesis of "educational internationalism" as promoted by the IBE, which was founded in 1925 as a private institution, from its establishment as an intergovernmental organization in 1929, cooperating with Unesco as of 1946, before becoming fully integrated into it in 1969. The IBE claims strict neutrality and objectivity, and has established itself, through the work of the International Conferences on Public Education (ICPE), as an international center for comparative education. In the first part of our article, in order to understand IBEs functioning and evolution after Second world war, we analyze the modus operandi of the Conferences' activities established in 1934 and the theoretical foundations of its first implementers, Pedro Rosselló and Jean Piaget. In the second part, we then examine the way in which the IBE negotiated its place during Unesco's creation from 1943 on, in order to gain recognition for its expertise and to move closer to it, while nevertheless retaining its autonomy and continuing its modus operandi. The third part synthesizes the product of the IBE as a factory from 1934 to 1968 -in collaboration with Unesco between 1946 and 1968- by identifying the main causes included in its work agenda, to promote access for all to quality education and to improve the status and education of teachers. The particularly turbulent post-war context put the IBE in the hot seat: through a number of emblematic events, we shall examine in part four how the IBE positioned itself at that time, while being hounded by the challenges of both the Cold War and colonialism. An institution that claims to guarantee the reciprocity of points of view and the possible construction of the universal must certainly have strict neutrality and objectivity as its tools; but to what extent does it contradict or even compromise itself by providing a forum for delegates who challenge the basic principles of equality and the right to education? To what extent can education be preserved from political interference? These questions are among those that the IBE's protagonists grapple with and that the analysis of its history invites us to explore in greater depth.

\section{The IBE, a Matrix of Educational Internationalism. Its Modus Operandi}

\section{Educational Internationalism}

We use the phrase "educational internationalism" which is our own, drawing on the vast literature on internationalism in the $20^{\text {th }}$ century (Laqua, 2011, 2015; Reinisch, 2016; Sluga, Sluga \& Clavin, 2017). Schematically stated, the noun "internationalism" designates the steps taken by a diversity of actors (intellectuals, experts, activists, diplomats, senior officials, etc.) to stabilize transnational exchanges via institutions, networks, and offices mobilized for common causes. These are supposed to go beyond national interests, even if Sluga (2013) has clearly demonstrated how internationalism and nationalism are intertwined. Indeed, any transnational initiative 
implies taking into account, or even building on national structures to transcend them. Internationalism also takes shape in people's consciousness through what Iriye (1997, pp. 1-50) calls "cultural internationalism": intellectual cooperation, artistic and literary creations, global collective memory, the development of social ideologies, transnational political movements. Education is one component of this. ${ }^{3}$

The educational internationalism of the IBE and its leaders was embodied, on the one hand, in its office, conferences, networks and publications with their global connections, and on the other hand, in the causes it defended, namely building peace on earth through science and education. The IBE's objective was to centralize educational documentation and to deal with world educational problems by applying methods of international collaboration. Looking to extend its action on schooling on a global scale, the IBE took governments as its first partners in 1929 in order to jointly elaborate what it called a "charter of world educational aspirations." that the logic of action and the operating principles of the first IBE (1925-1929)including neutrality, objectivity and scientificity-no longer constituted its raison d'être? Not at all. The demand for independence, which presupposes the affirmation and guarantee of a politically neutral position, which is, moreover, resolutely objective and scientific, was on the contrary strengthened at the same time as the institution became intergovernmental. A twofold challenge was at stake in the assertion of this technicality and neutrality: 1 . to permit genuine international consultation, while avoiding the risk of States perceiving any interference in the scope of their educational prerogatives; 2 . to guarantee the freedom of action and scientific credibility of the IBE itself, a condition of the universality to which it aspired, which would ensure its recognition as a world forum for education. This is also the reason why the direction of the IBE was entrusted to the scientists Piaget and Rosselló, who would shoulder these responsibilities for almost forty years (1929-1968).

Over the years, structures became more formalized, research more systematic, and methods more rigorous. Thanks to its modus operandi, expertize in terms of intergovernmental cooperation in education was developed: in this way, did the IBE manage to avoid the perverse effects of diplomatic relations absorbed by the construction of a consensus, expunging its contradictions through conventional and stereotyped discourse? Cross-referencing the analysis of official discourse with that of others, less flattened sources raises doubts about this. ${ }^{5}$

Let us focus on the IBE's modus operandi for producing this "charter of world aspirations". 


\section{A Production Center of Educational Knowledge whose Emblem is the Institution of the ICPES}

Whether or not they were affiliated to the IBE, small and powerful countries around the world were invited to participate in the surveys that preceded the ICPEs, then to meet in Geneva to consult in order to seek solutions to identified educational problems.

These first forums of intergovernmental dialogue brought together delegates (ministers, diplomats, researchers, educationalists, etc.) from all over the world for 5 to 15 days. ${ }^{6}$ Government delegates were invited to present and discuss the "highlights of the education movement", based on the monographs submitted by participating countries. This inventory of reforms was accompanied by school statistics, which were supposed to attest to "progress in schooling". From 1933 onwards, these pages were published in the International Yearbook of Education and Teaching, accompanied by a comparative analysis and synthesis carried out by the comparative scholar Rosselló. Thirty-five countries contributed to the first Yearbook in 1933, followed by 53 in 1934, and 94 in 1965, i.e. some $2 / 3$ of the so-called sovereign countries. ${ }^{7}$ The collected data, according to their creators, would make it possible "to get an idea of the progress of education in the world" (ICPE IX, 1946, Minutes, p. 7). This perspective gave rise to exchanges during the ICPEs, and participants were thus invited to discover the innovations highlighted in partner countries and, when appropriate, to make use of them in their own school policy.

The ICPEs that began in 1934 were also intended to address the educational issues deemed most pressing. Two or three themes considered as important were selected as priorities; the IBE then conducted an international survey on these themes, which aimed to make known the different facets of the problem throughout the world and the experiences of those involved in overcoming them. On this basis, the Conferences discussed recommendations that could solve these problems. The recommendations, which were submitted to the consideration of States during the Conferences and adopted at their conclusion, had no binding value: the dread of interfering in nations' educational purview endured.

Subtle arguments were used to turn the freedom contained in this absence of constraints into responsibility. It would be in the interest of each government to possess the best possible education system, a guarantee of the country's intellectual and economic performance: emulation between countries would therefore suffice, with each country being invited to learn from the experience of others in order to perfect its education system. Each country was free to state its position, to amend or oppose the recommendations. But the compensation of this freedom was clearly stated from the outset: by attending, speaking, or making written submissions and voting on recommendations, national delegates were committing the governments they represented (ICPE III, 1934, Minutes, pp. 8, 22-23, 30). The commitment would be all the more demanding since it was freely given (Hofstetter \& Schneuwly, 2013, 2020). 
Rosselló and Piaget can be considered as the two main designers of the ICPEs's modus operandi, although they were, of course, strongly supported by IBE staff and more particularly by the Secretary General, Marie Butts (1870-1953), who was active from 1926 to 1946 . However, it is interesting to note that their theoretical backgrounds to their contributions to the conceptualization of this modus operandi was rooted in different fields. Rosselló embodied and resorted above all to comparative education, while Piaget relied on his empirical and theoretical work on moral judgment. We postulate that it is this double anchoring and, above all, the ability to articulate it, that underpin the originality, effectiveness and sustainability of the modus operandi of these first intergovernmental forums on education.

\section{Comparative Education: Articulating the Local and the Universal}

How did Rossello conceive of the comparative education which structured his scientific identity $?^{8}$ In his writings (including reports and correspondence), he provided its theoretical and methodological groundings, and proposed it as an approach both for scientific research and for intergovernmental collaboration: according to Rosselló, comparative education was the key instrument enabling small and large powers alike to meet, share their concerns, and draw from the experiences of others in order to collectively develop-with the support of objective data-solutions to the world's educational problems. Rosselló, who was wary of all forms of hegemony, problematized the relationship between the particular and the universal: he postulated that only by taking into account local data and analyzing it objectively can universal perspectives be developed, whether they are translated into scientific theories (comparative education as a discipline) or pedagogical recommendations (comparative education as an approach to intergovernmental collaboration). These theories and recommendations should find relevance at the international, national and regional levels, as their application requires adjustment to local contexts. Local characteristics would even be reinforced, in that they could be disseminated and discussed, or even valued and re-appropriated by others. According to Rosselló, this was the primary role of the IBE, which he conceived and profiled as a center for comparative education.

How can one avoid the power issues that commonly plague relations between governments? Precisely, by offering a forum to each party, whatever it may be (NorthSouth, empire, small country); a forum supposedly preserved from any political inference, which would allow each one to express itself without arousing judgment. The tools of comparative education -aimed at simple comparison between data without bias would make it possible to rule out, theoretically at least, confrontations and controversies. No one is allowed to interfere with a country's educational choices. This is achieved at the risk of endorsing by its silence decisions that were in fact contradictory to the IBE's guidelines, as was the case with certain resolutely nationalist 
decisions adopted by authoritarian regimes at the end of the 1930s (Hofstetter \& Schneuwly, in press, a).

What was the objective value of the presented facts? Clearly, the national reports, written by the ministries themselves, present their pedagogical decisions and changes in their most advantageous light. For an institution that prided itself on working to the highest scientific standards, was it not a sign of great credulity to take the data as objective? Piaget and Rosselló conceded that government reports may contain some exaggeration, with governments using this forum to present an advantageous and innovative picture of their practices. But, at the time of assessment, Rosselló bitterly complained that the field of education was the target of more tenacious and sharp criticism than other fields and disciplines: the officiality of sources in education would stain the data from the outset "with an original sin" that would automatically invalidate their relevance, even though, he denounced, most international surveys on production, economic life or social achievements are also based "on official data without their probative value being de facto disputed a priori!” (Rosselló, 1963, p. 206).

\section{From Egocentricity to Reciprocity-From the Individual to the Universal}

While Rosselló was indeed the mastermind behind the preparation of the Yearbooks and comparative analyses, Piaget contributed substantially to the conceptualization of these methods of international cooperation and their application in the intergovernmental arena. He did so, we believe, by combining the dual stance of the scholarly psychologist and the diplomat of educational internationalism (Hofstetter \& Schneuwly, in press, b; Xypas, 1997). Indeed, Piaget drew on his empirical and theoretical work on moral judgment to refine the IBE's modus operandi. The interdependent notions of solidarity, reciprocity, freedom and rationality were presented as the foundations of global understanding, not only of future generations and their educators, but of everyone, including ministers. Piaget demonstrated that methods of cooperation allow for the passage from egocentricity to reciprocity, from the individual to the universal, in other words, to internal solidarity:

Understanding between individuals of different races or nationalities must be the primary aim of any educationist who seeks to contribute to an international rapprochement. [...] What we need is a spirit of cooperation whereby each will understand all the others-an 'internal solidarity' which will not eliminate individual standpoints, but will bring about mutual comprehension and establish unity in diversity. [...] It is this correlation of standpoints that we call cooperation, as distinct from uniformization or the Utopian search for an absolute viewpoint. (Piaget, 1931/2011, p. 80). 
However, what is true in the educational field would also be true in other relational fields, including international and intergovernmental cooperation. Piaget therefore invited government delegates to adopt the same position: work, dialogue, cooperation, in a dynamic of reciprocity in order to understand others and be enriched by their experiences. A careful analysis of the IBE's modus operandi enables us to state that Piaget experimented with the methods of co-operation, teamwork and "selfgovernment", which he theorized by proving that they foster the transition from egocentricity to reciprocity, thus enabling access to moral judgment, that is to say to rationality and truth, the origin of intelligence.

It is toward the implementation of this decentering-reciprocity, unity-diversity, that Piaget and Rossello summoned the dozens of ministers and experts when they participated in the IBE surveys, discussed the results and drew up the recommendations at the ICPEs until the end of the 1960s. The aim was both to promote these practices and principles in the world's schools, and to translate them into the modus operandi of the IBE and its Conferences. This is what the IBE's protagonists then called the methods of international concertation and co-operation, transposed here to an intergovernmental level.

In so doing, the IBE was transforming itself into a World Centre for Comparative Education, and it was in this capacity that the leaders of the IBE would be heard at a time when the initial foundations of Unesco were being laid.

\section{Continuity of an Operating Mode in a New Context}

During the Second World War, while struggling to pursue its documentary and scientific activities, the IBE contributed above all to educational reconstruction through its Intellectual Assistance Service for Prisoners of War (Boss \& Brylinski, 2020). In this way the IBE was preparing a way out of the war: the more institutionally and financially solid it would be, recognized for its scientific work and its humanitarian commitment to education, the better it would be able to negotiate its place in the reconfiguration of the landscape of international organizations.

\section{A Marriage of Convenience}

When the allies began talks to set up the future Unesco within the more general framework of the complex construction of the UN system, Marie Butts, the Secretary General of the IBE, who had been detained in Great Britain since 1940, became the mediator between London and Geneva. As an "involuntary but competent ambassador", she became closer to influential people (Mylonas, 1976, p. 332). ${ }^{9}$ Butts listened particularly attentively to the negotiations within the Council for Education in World Citizenship. She was even co-editor of the report Education and the United 
Nations, which served as a reference for the Conference of Allied Ministers of Education in May 1943 (p. 196-7). For example, her dozens of contacts included the American Grayson Kefauver, ${ }^{10}$ author of a first draft of the statutes for what was to become Unesco, and W. E. Richardson, the right-hand man of the British Minister of Education, who was also responsible for setting up this international organization. Both were kind enough to inquire about the IBE's position on this initiative.

The position of the IBE Director Piaget with regard to the future Unesco was clear from the outset and guided its construction: only a technical, objective and impartial body, such as the IBE, could make intergovernmental collaboration possible:

What if another organization arose elsewhere more or less similar to ours? Well, one of two things: either it will be inspired like us only by the desire for objectivity and collaboration, which are indispensable for peace, and we could only co-ordinate our common efforts sooner or later, or it will be directed toward other goals and there will certainly be, in the end, a need for an impartial and technical body, such as the International Bureau of Education in Geneva. (Piaget, 1943, p. 16)

IBE officials were actively involved in the establishment of what was to become Unesco. Commenting on the draft statutes sent to them by Alfred Zimmern (18791957), Executive Secretary of the Preparatory Commission for the Constitutive Conference of Unesco, they stressed the need to provide for Specialized Agencies to which the nascent Unesco could transfer certain functions, including organizing specialized international conferences. As a result of these intense exchanges and after having participated in the preparatory conference in London in 1945, the IBE drew up its report:

While it is agreed that Unesco's field of competence should be as wide as possible, it is at the same time accepted that Unesco should share its tasks with other public international institutions-institutions which would thus become specialized at the secondary level-which would thus complement Unesco's direct action. ${ }^{11}$

The IBE therefore aimed to become such a "specialized secondary" institution while maintaining its independence. It could lay claim to certain assets in the negotiations for its future: a solid experience in the field of comparative education; an impressive body of world educational documentation; a proven modus operandi, i.e. surveys and the dissemination of writings that continued during the war and the ICPEs that were resumed after the Armistice; a reputation as the leading technical agency for intergovernmental consultation in education; the influence of the work of Piaget recognized as a diplomat of educational internationalism; and last but not least, good financial health.

Negotiations between Unesco and the IBE began in January 1946. The positions were contradictory, as is shown by two memoranda of July 1946: the first, drawn up by 
Unesco representatives, provided for the full and rapid integration of the IBE; the second, drawn up by IBE officials, proposed relative autonomy with a joint committee, financial support and regularization of staff regulations. "If things do not settle down by then, we will be able to fight the battle in November," wrote Piaget in preparation for the last round of negotiations scheduled just before the Unesco Constituent Conference in the autumn of 1946.

After bitter discussions, a transitional solution was found: to entrust the Unesco-IBE Joint Committee with the task of specifying the modalities of collaboration. This path of linkage, recommended by the IBE, was implemented. Considered to be "Unesco's precursor"12 in the field of education, it therefore fitted into the complex United Nations system. Ever the pragmatic diplomat, Piaget called it a trial marriage, and by 1948 , Unesco Assistant Director-General Clarence Edward Beeby remarked that it was a marriage of convenience that proved to be a marriage of affection (ICPE XI, Minutes, 1948, p. 21).

The provisional agreement was stabilized in the 1952 Convention. Conceived as an independent technical body, the IBE maintained all its mechanisms: educational documentation, yearbook, Bulletins, surveys, and more particularly the ICPEs. The IBE retained its Geneva headquarters, managed its budget with relative autonomy, possessed an independent management, recruited its own staff -who have been granted the status of international civil servants. But this came at a price: new decision-making mechanisms were needed via a "joint committee", composed of three representatives of Unesco, on the one hand, and of the IBE on the other; it was this commission that ultimately determined the topics of the surveys and the countries invited to the ICPEs. As we shall see, this procedure was not without its frictions, which strained the IBE's sacrosanct values of political neutrality and universalist aims.

Its collaboration with Unesco gave new scope to the IBE's action in terms of legitimacy, representativeness of the ICPEs and inclusion within wider relational networks.

\section{Increasingly Global Networks}

The IBE's internationality can be observed in two ways: first through the number of States and governments affiliated to the IBE that commit themselves to paying their membership fees (also through various arrangements). Figure 1 shows the rapid growth in numbers between 1946 and 1968. 


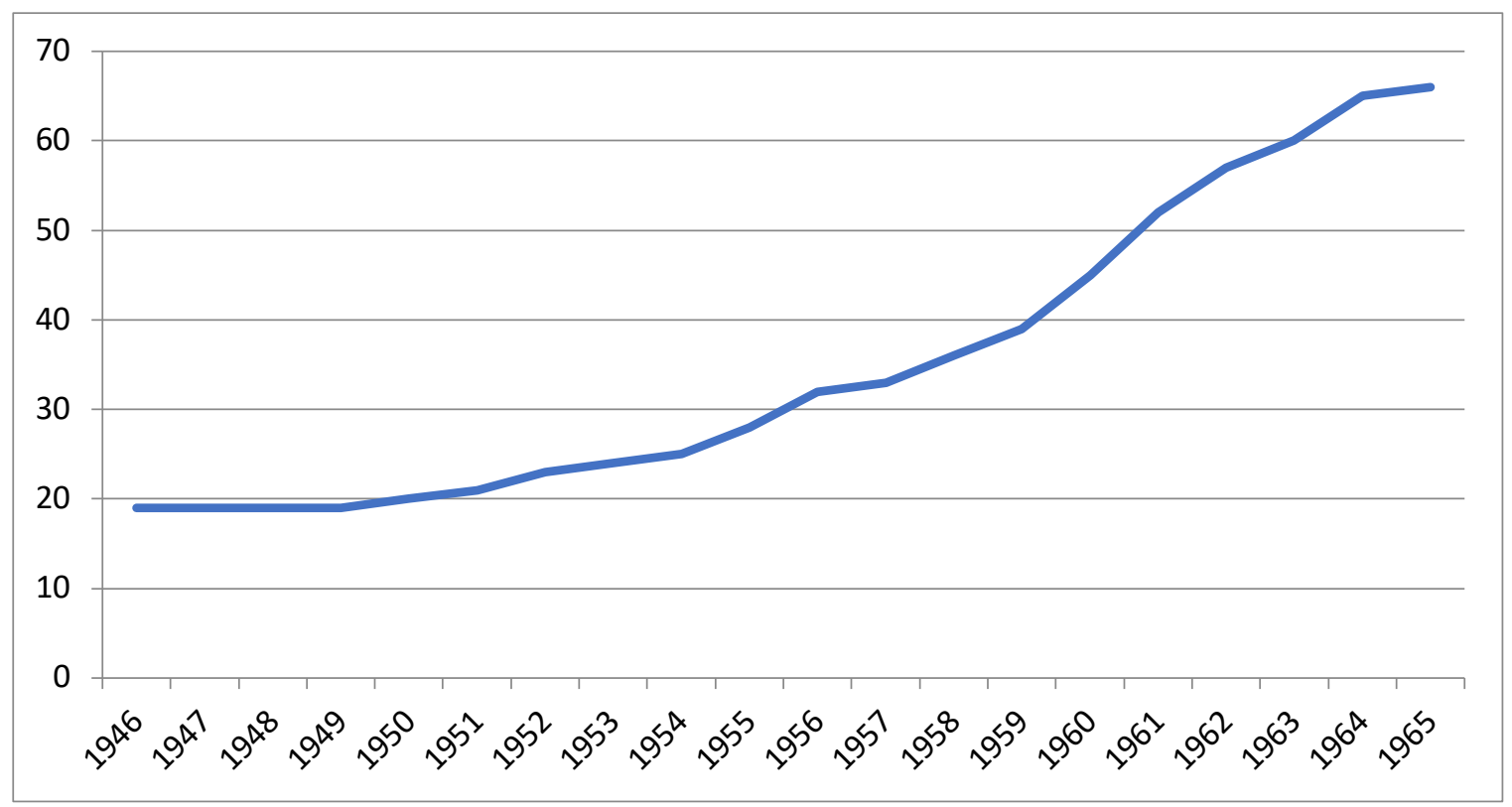

Figure 1: Number of IBE State members 1946-1968

The number of State members tripled in the space of 20 years. This is directly linked to the decolonization process, but also to the adhesion of Anglo-Saxon and Northern European countries, which had long been reluctant to join. Thanks to the collaboration with Unesco, becoming a member of the IBE became almost evidence for every country in the world.

Another way of evaluating the IBE's internationality is to observe the number of countries participating in surveys and conferences, which was much higher than the number of its members, as shown in figure 2 . 


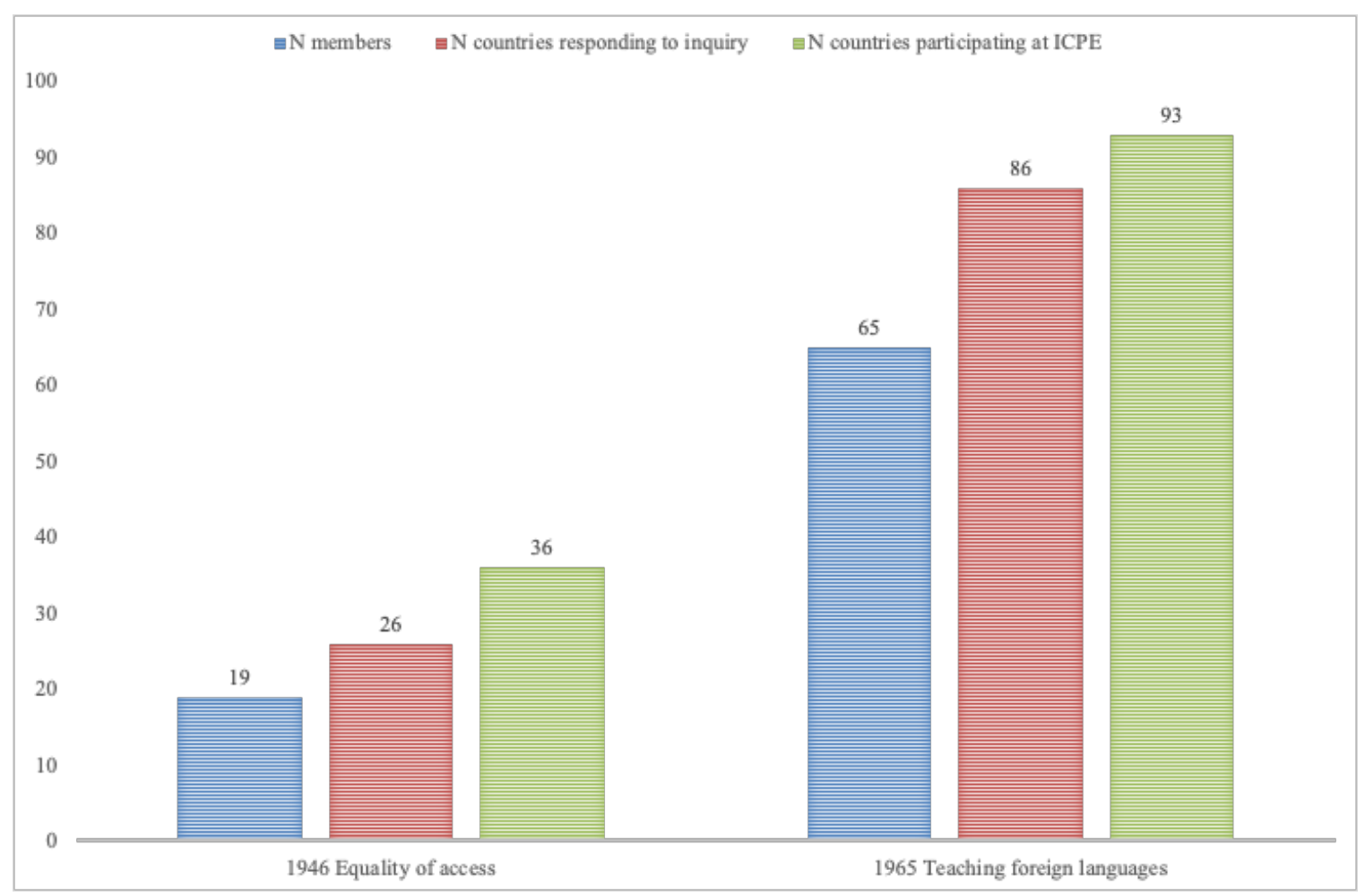

Figure 2: number of members of IBE, number of countries responding to inquiries in 1946 and 1965 and participating in the 1946 and 1965 conferences

Of the about 70 countries surveyed worldwide in $1946^{13}, 26$ participated in the survey and 36 in the ICPE. The number of countries rose to about 120 in 1965; 86 participated in the surveys, 93 in the ICPE, i.e. three quarters. Again: this quasiuniversal participation to the inquiries and ICPEs is probably the result of the common organization with Unesco.

\section{The Products of the Modus Operandi: “Unesco's Body of Educational Doctrine" 14}

\section{Overview and Principle in Focus}

A global and synthetic analysis of surveys and recommendations produced between 1946 and 1968, the period of collaboration with Unesco, makes it possible to categorize the themes dealt with by the IBE. 
Table 1

Categories of topics dealt with by ICPEs between 1946 and 1968

\begin{tabular}{lcc}
\hline & $\mathrm{N}$ & $\%$ \\
\hline Structure and organization of systems and school flow management & 16 & 34.0 \\
Curricula and school subjects & 19 & 40.5 \\
Education, status and recruitment of teachers & 12 & 25.5 \\
\hline Total & 47 & 100.0 \\
\hline
\end{tabular}

We note the emphasis placed on the organization and structures of school systems, on the one hand, and the contents and methods of teaching on the other. Teachers, their training, recruitment and status make up the third facet favored by the IBE. This chapter synthesizes the IBE's guidelines adopted from 1946 to 1968, but which had already been sketched out in the 1930s. They were the result of a genuine process of discursive distillation resulting from the preferred modus operandi: the many replies to the survey questionnaires, their synthesis in reports, discussions in the ICPEs, and, in the final phase, the recommendations that condensed their aspirations. The production-condensation of the data into recommendations supposed to reach a consensus-produced a vision, necessarily ideal, purified by the distillation itself. While the country reports revealed a great diversity of practices, which might equally reveal deep divergences, the synthesis report subsequently attenuated them, and the minutes of the consultations, where contrasting positions were outlined, weakened them further, and the recommendations made them disappear in favor of a few articles approved by all.

The focus of the IBE remained on the intangible principles of justice, peace and solidarity, which presuppose universal access to quality schooling that allows for the harmonious development of each individual. It should be made clear from the outset that this point was unanimously supported by the leaders of the IBE and Unesco, even during the sensitive period of negotiations during which they defined their collaboration agreement. ${ }^{15}$ This synergy was to be particularly profound during the four years (19491952) in which Jaime Torres Bodet (1903-1974) was Director of Unesco, who shared with Piaget similar humanist and universalist convictions. Their respective interventions during the ICPEs of 1949 and 1951 bear witness to this. Echoing Piaget's previously cited words, the Director-General of Unesco, Torres Bodet, stated that the mission of the $20^{\text {th }}$ century was "to eradicate illiteracy, another form of slavery", which affected more than half of the world's population. The "satisfaction of the cultural rights of man is one of the indispensable conditions for his dignity and the free development of his personality" (ICPE XII, 1949, pp. 22 and 25). He also appealed to the supreme duty of the "Gentlemen" of the Conference (the 80 persons present only included 7 women) to 
"become the architects of that society in which human rights and freedoms will reign" (p. 27). This universality principle is the one to which the IBE aspired, both with regard to the rights of the countries represented in its Conferences, and to the rights of juvenile populations and their educators to whom they dedicated their work.

\section{Creating a More Egalitarian School System}

The educational reconstruction of the world was the primary aim defended in the ICPEs of the immediate post-war period, during which time the IBE too was presented as "a pioneer in the great work of international education" (1949, p. 20). In the opinion of the 1946 Conference's Swiss Master of Ceremonies, this required first and foremost the re-establishment of "the ABCs [...] of a normal public education", closely coupling social justice and school justice "to correspond to the new political aspirations of peoples in the field of education" (Picot, ICPE IX, 1946, Minutes, p. 20). These were the main thrusts of the recommendations made concerning the material and organizational infrastructure of public instruction systems, especially the sensitive issues of managing school flows and universalizing conditions of access to education and culture. These themes were repeatedly placed on Conference agendas, demonstrating both the importance accorded to them-and thus the hierarchy of the IBE's missions and those of its partners-and the persistence of the raised problems despite the collective mobilization to resolve them: this was the case in regard to the conditions and equality of access to schooling (surveys initiated with the International Labor Office), the consideration of fragile and vulnerable populations (early childhood, specialized education, pupils in difficulty, so-called backward, retarded pupils, etc.), the promotion of education for all, and the promotion of the rights of children with disabilities (e.g. the right to education, the right to education for all) or potentially discriminated groups (women, young people in rural areas).

The Conferences on the extension of compulsory education (1951) and on the conditions of access to secondary schools (1946), previously dealt with by the IBE in 1934 , bear witness to this. In the immediate post-war period, the key words of social and educational justice and equality of opportunity were used as if they were taken for granted and bolstered by the 'march of educational progress in the world'. Some, however, pointed to the gap between these generous principles and the fate of the millions of children who did not possess the privilege of going to school, and who would in due course add to the legions of illiterate, unemployed and delinquent people.

A number of discourses converged to advocate the free development of the human person and equality in education, regardless of ethnic, social, racial or sexual affiliations. Opposing Malthusianism at school and the elitist definition of secondary education, still very much commonplace during the Inter-War period, and under the effects of shock of the 1929 Wall Street Crash, as early as 1946 the delegates 
advocated for a unification of the school organization chart, the extension of compulsory education, and the broadening of recruitment to secondary education thanks to scholarships for deserving pupils and, above all, the improvement of selection, differentiation and guidance methods. In this respect, Piaget's responses were particularly striking: "Secondary school is a school for the gifted, regardless of social class, leading to higher education or vocational training. The elite is constituted therein on the basis of aptitudes" (Minutes, 1946, p. 27). Piaget thereby advocated for a new form of democratization, which favors guidance over selection, requiring better psychological qualifications for teachers. One hypothesis could be tested in this respect: would the psychology embodied by Piaget-whose scientific influence was growing steadily at the time-have made it possible to reach some form of consensus by avoiding confrontation with more clearly (class-based) sociological and political issues?

\section{An Expanded Education of the Person Useful for Daily Life, through Active Methods Based on Psychology}

The work on curricula and school subjects was guided by general objectives that cut across all reports and recommendations on this topic. The contents and methods must be oriented toward a broad and general education of the person. The natural sciences, for example, have "an informative purpose in making pupils aware of the interdependence of beings and the self, the development of general culture, and the acquisition of aesthetic and moral values, such as the cult of nature and respect for life" (Unesco-IBE, 1952, Minutes, p. 80). The adaptation of pupils to the modern world, another general purpose, contributed to the progress of humanity. The study of the environment, an 'interdisciplinary' approach proposed in particular for primary schools, is a perfect example of this:

Having regard to the rapid growth in population and ever-increasing industrialization, the study of environment should awaken and strengthen a love of nature, a desire to help to preserve it and protect its resources to increase these resources by means of work and to use them wisely with a view to making them meet requirements and improve living conditions. (Recommendation, $N^{\circ} 65,1968$, p. 359).

International understanding, the IBE's original general objective, remained the focus of reflection on contents and methods. The teaching of modern languages, for example, "contributes to better international understanding and the establishment of peaceful and friendly cooperation among peoples". The aim is to encourage governments to reflect on psychological and didactic means designed to avoid the feeling "that the child believes him/herself to be at the center of the world and to 
increase the feeling of moral unity of the human race" (Unesco-IBE, 1949, Recommendation, $\mathrm{N}^{\circ} 26, \mathrm{p} .70$ ), nevertheless without neglecting to foster a love of the homeland.

The fundamentally disciplinary structure of the curricula was in no way questioned, quite the contrary. The generic table of disciplines established by the IBE showed that mathematics and natural sciences were at the top of the list almost everywhere in the world, both at primary and secondary levels. As one rapporteur pointed out, one found oneself "in a mathematical high ground never before attained" (ICPE XIX, 1956, p. 141). Knowledge of the natural sciences was particularly important "in view of the everincreasing inroads of technical science into everyday life" and "to ensure economic welfare" (ICPE XII, 1949, p. 103). As if to counteract what could constitute a scientific or even utilitarian drift, manual work, physical education and the plastic arts were valued in parallel, in order to guarantee a "complete and harmonious development of the personality" and an "integral education" (Recommendations, № 22, 1947, p. 59; $\mathrm{N}^{\circ} 30,1950$, p. $81 ; \mathrm{N}^{\circ} 41,1955$, p. 159).

The organization of knowledge within disciplines should respect the stages of development of students' interests and abilities as revealed by developmental psychology. This line of argument was ambitious. In mathematics, the indications given for the construction of the curriculum were quasi deduced from the psychological description of development: "Let the nursery school already provide the child with the opportunity to discover, through a set of effective and personal actions, the elementary relationships (inclusion, order, correspondence, etc.) that make up number and space" (Recommendation $N^{\circ} 31,1950$, p. 82). The elements of Piagetian theory on number construction are expressed almost to the letter.

The reference to Piagetian developmental psychology almost inevitably led to a constructivist approach to teaching that informed all discussions on school curricula and content. Let us take reading as an example: "The so-called global methods advocated by psychology are more in keeping with the child's mental possibilities and spontaneous interests" (Unesco-IBE, 1949, Recommendation N² 28, p. 121). This went hand in hand with a sometime sharp criticism of traditional teaching methods, those "old methods which have put so many children to the torment of death..." (Torres Bodet, ICPE XIII, 1950, Minutes, p. 25). The positions were unanimous and intangible: only active methods guarantee effective learning. It was tirelessly asserted that "the school authorities give preference to so-called active methods" for disciplines as contrasting as the natural sciences and the plastic arts.

\section{Teachers at the Heart of the School System}

For the IBE and its partners, the quality of schooling depended on the quality of the teaching staff. The first condition was a clearly defined status. At conferences on 
teachers' working conditions and salaries, delegates unanimously advocated that teachers should have a clear contract, job security, social security and welfare, a decent salary, guaranteed paid holidays and a pension. These elements were regarded as a condition for the proper exercise of their profession. For example, at the 1953 ICPE on the situation of primary teachers, participants were concerned about their low pay and gender discrimination. It was therefore important that "promises of promotion and salary increases should be sufficient to retain and encourage teachers", who should "benefit from social security measures, including retirement pensions" (p. 70). The adopted recommendations clearly denounced "all discrimination between the sexes" ( $N^{\circ} 39,1954$, p. 150). The IBE still insisted that the teaching profession should remain united: solidarity among teachers at different levels (and with their hierarchy) seemed to be regarded as the basis for solidarity among students of all origins and as a means of building the profession. In this sense, the IBE was already working toward what we now call the professionalization of teaching.

At the heart of this professionalization lied a high level of training. The IBE was striving to create a movement to ensure that all teachers benefited from a sound general culture and quality professional training. It was therefore after completing secondary education that candidates for primary education should begin their professional training. For the secondary school teacher, who had a secondary school diploma, it was argued that he or she should also benefit from professional training. Mastery of the knowledge to be taught was therefore not enough to transmit it. There was a very clear tendency to encourage a trend toward extended education, so that all teachers acquired a broad culture from which their students could benefit, and in turn transmit to the whole population. This education must include both internships and practical experience in the field. Education should therefore also be provided to the teachers who receive and supervise these trainees. What is also striking is the insistence on very advanced education at the theoretical level, including substantial work on didactics (sometimes also called teaching techniques or methodology). The IBE and its partners advocated an education based on the results of educational and psychological research, so as to be able to guide and select pupils, but also to be familiar with the development of children and adolescents. Although the Écoles normales, Lehrerseminare, or teacher-training college was the main institution for educating teachers, IBE officials led by Piaget recommended Pedagogical Academies, and even the transfer of vocational education of teachers to universities. Notwithstanding these pleas for an extension of schooling and qualifications for teachers, some dissenting voices expressed concern about the shortage of teachers and the negative consequences of extended education on the recruitment of candidates.

The recommendations resulting from the surveys and debates in the ICPEs constituted what Piaget and Rosselló called a "charter or a kind of International code of public education". The expression that was ultimately favored, "charter of global 
aspirations in public education", reduced its prescriptive scope. During the debate of the IBE/Unesco Joint Committee on the publication of the collection of Recommendations of the ICPEs from 1934 to 1958, Julien Kuypers, a member of the Executive Board of Unesco, considered that "these recommendations do indeed constitute what might be called Unesco's educational doctrine". René Maheu (19051975), Director ad interim of Unesco (and future Director), added that "the 47 recommendations so far adopted constitute a veritable "body of educational doctrine'", even wondering whether "some of them might not subsequently be the subject of international agreements" proposed by Unesco (Minutes of the 26th meeting, 6 July 1959, p. 3, B37, A-BIE).

\section{Divergences and Tensions-Traces of the Cold War and Decolonization}

As we have previously discussed, the relations between Unesco and the IBE from 1947 to 1968 , clarified well on paper, were mainly managed by the Joint Committee composed of representatives of both institutions. It was mandated to take most decisions, including defining the themes of surveys and conferences. More research is required on its negotiations, since the delegates of the two institutions did not always defend the same approaches and visions as to the distribution of mandates between Unesco and the IBE, and the relevance of the IBE's modus operandi. However, let us make clear from the outset that during this period, there was an amalgam between the IBE and the figure of Piaget, who established himself as a true "diplomat of educational internationalism" "16: in addition to the responsibilities delegated to him by Switzerland, he headed the Unesco Department of Education ad interim in 1949, drew up the "Plan of Action" (1951/1997) ${ }^{17}$ for education for international understanding, and became a member of its Executive Committee between 1950 and 1952. The celebrations of the IBE's $25^{\text {th }}$ anniversary in 1954 enabled Unesco Director-General, the American Luther Evans (1902-1981), to express a vibrant homage to Jean Piaget for his talents as an administrator, diplomat and scholar, whose work was of universal renown. On behalf of the State Council of Geneva and the Swiss Government, Albert Picot for his part presented the IBE and especially its Conferences as the body that has succeeded "in saving education from international ostracism" (1954, Minutes, p. 20). While a step in this direction had certainly been taken, we know that nationalism smoldered beneath internationalism, and that education was far from being a terrain free from such interference, even within the ICPEs. ${ }^{18}$ 


\section{The Meddling Influence of the Cold War}

The Cold War manifested itself namely through the question of which countries were to be invited to the ICPEs ${ }^{19}$ as early as 1954 by which time countries of the communist bloc once again renewed their active participation. The Polish delegate "expresses his astonishment to see China represented at this Conference by a delegate from Taiwan", supported by the delegates from Hungary and Russia, who denounced the situation:

Only the reactionary policy that supports the Kuomintang, first and foremost the United States, makes it possible ${ }^{20}$ for the Kuomintang, contrary to common sense and historical justice, to present itself as China's representative before a number of international organizations, including Unesco. (ICPE, 1954, XVII, Minutes, p. 22).

The problem remained unresolved. Every year the IBE Council, newly joined by the USSR (1955), raised the question of extending an invitation to China, a question that Piaget faithfully relayed to the Joint Committee: "The IBE is interested in the development of education in all countries regardless of political systems. Thus, at the time when Spain was not a member of Unesco, it had always insisted that it should be invited" (Minutes of the Joint Committee, March 25, 1955, p. 4). The reply of the Director of Unesco's Department of Education to Piaget in the same conference remains intangible:

China is on the list of States to be invited to the Conference; it remains to be clarified which China it is. As far as Unesco is concerned, the question of China's representation was raised at the eighth session of the General Conference (Montevideo), which decided in favor of the Republic of China.

The IBE's principle of universality was being undermined. Moreover, the principal of political neutrality was seized upon to support this state of affairs when, in 1965, the Russian IBE delegate denounced the illegality of representation of the Republic of China on the IBE's Executive Committee: the Chinese delegate from Taiwan replied that "the participants in this meeting are there to discuss the IBE's activities and not to raise political problems" (Minutes of the Joint Committee, February 2, 1965, p. 2).

The case of the German Democratic Republic (GDR) is equally instructive. At the $30^{\text {th }}$ meeting of the IBE Council, Poland and Belarus ${ }^{21}$ complained about the educational propaganda of the Federal Republic of Germany (FRG) which included Berlin. More broadly, in a reply to a letter from the delegate of the FRG claiming this right, the delegates from Russia, Belarus and Ukraine criticized, "the attempt of the government of the FRG to pass itself off as the only legitimate German government... The existence of the sovereign German state-the German Democratic Republic-is a fact that no one can ignore any longer". Yet the German delegate persisted, writing: 
East Germany is merely an occupied portion of German territory. The so-called German Democratic Republic in East German is a regime imposed upon and not chosen by the population. The freely elected Government of the Federal Republic of Germany is the only Government entitled to speak for the German people in international affairs. (Letter at the president of the IBE Council, July 23, 1965, attached to the minutes of the $30^{\text {th }}$ Council meeting).

The chairman of the Council, supported by several members, "thought they should avoid all questions of a political nature and eliminate anything which could give rise to such discussions" (Minutes of the $30^{\text {th }}$ meeting of the IBE Council, July 17, 1965, p. 3).

It is obvious that the IBE hemicycle was rife with political interference, despite its minutes being very allusive in this respect, or deliberately evading these contradictions in order to increase general agreement. It is true that adversarial debate was one of the practices recommended by Piaget and Rosselló to reach consensus when defining IBE recommendations; but these debates were of a pedagogical and scientific nature, not political. However, the dissociation of the two appeared illusory in the fiery context of the 1960 s and the liberation process of colonized countries.

\section{Former Colonies Take a Stand}

The North-South tensions increasingly being expressed within Unesco ${ }^{22}$, crystallizing around the question of colonialism, had a direct impact on the IBE: can a real distinction be made between technical and political issues, and can it be argued that scientific objectivity guarantees impartiality? At the 1963 ICPE, which brought together more than 80 States, many of the newly independent African countries participated with full rights. They took advantage of this world forum to protest against Portugal's colonialist policy that offended "human and children's rights and the sacred principles of education" and demanded its exclusion (ICPE, 1963). While condemning colonialism, both the Assistant Director of Unesco and the Director of the IBE unanimously rejected the legitimacy of the ICPE to exclude an invited member, as this was contrary to its neutral and universalist character, considering also that other bodies and organs had that function. The African delegations succeeded in bypassing the situation by having their resolution adopted on 4 July 1963; the ICPE continued its work.

At the 1964 Conference, the African delegations once again rose up; dissenting voices were raised, a draft resolution from the delegations of the Latin American countries attempted conciliation, points of order and compromise proposals multiplied, while the Directors announced their intention to withdraw and suspend the Conference if it did not keep with its mandate and suffered external political interference. The African delegations managed to obtain a vote on their resolution, ${ }^{23}$ arguing that a country that still defended colonialism could not be accepted, that technical questions 
and politics could not be separated. As proof, the representative of Sierra Leone cited an extract from an official Portuguese bulletin which stated that "the objectives of education are to bring the indigenous people from the wilderness to civilization" (p. 62). In the same voice, the director of the IBE and the Assistant Director of Unesco deplored this interference, which was considered illegal and self-destructive, and which instrumentalized the Conference and compromised its qualities of technicality, objectivity and universality. Before suspending the session, Piaget rhetorically asked: "Why did you choose the ICPE for this anti-colonialist demonstration?", to which he answered:

Because its Secretariat is weak, it has been assumed and even claimed. But, gentlemen, the fact that we are weak politically is what has so far given us our moral strength and the strength of our objective and active neutrality. (ICPE XXVII, 1964, p. 77).

The 1965 Conference resumed its work by adopting a statute and procedural regulations, confirming its modus operandi and main tasks.

Piaget remained involved in his enduring capacity as IBE Director, but was about to hand over the reins. This he did in 1967, specifying that "in the crisis situations that we have gone through, I did not dare to submit this resignation, which would have appeared to be either a movement of mood or a sign of discouragement" ${ }^{\prime 2}$. The possibility of the IBE's full integration into Unesco opened up "new prospects" that others would have to carry and fulfill.

\section{Conclusion}

Unesco, the world organization for education, science and culture, has several ancestors and precursors. The IBE, the first intergovernmental institution in education, was considered by several contemporaries to be one of them; and our analysis shows that indeed the 'pioneering' experience of its leaders was called upon to build the new institution. In addition, the decision was taken to preserve the existence of the IBE as a technical body in order to benefit from its expertise in intergovernmental consultation: the IBE thus became a partner of Unesco in carrying out one of its functions, namely to document and discuss the progress of education in the world in order to derive guidelines for its deployment. While Unesco was engaged in major political projects of educational construction and reconstruction, the IBE was pursuing its technical and scientific work, but henceforth with and for Unesco: the latter, which Piaget referred to as the potential "praying mantis", did not devour the IBE, but married it. According to Rosselló, the IBE became the "little brother", and Piaget specified that Unesco, while a "sister younger in age as the IBE, became its older in greatness and wisdom" (1951, Minutes, 28). Finally, in 1954, he described them as twin sisters (Minutes, p. 119). The 
twinship was not based on common DNA, a fact which they seem to have been aware of as they strove to peacefully respect the differences in their functions and mandates.

This enabled the IBE to continue to produce, in accordance with its own modus operandi, the body of Unesco's educational doctrine: the "charter of World Educational aspirations". The modus operandi, elaborated by the IBE well before partnership with Unesco, constituted the tool that ensured this production in the IBE as a factory of pedagogical guidelines. The Charter, 'distilled' from the many voices from all over the world expressed through the surveys, is also branded by the aims and fundamental convictions of the IBE's actors: universal access to education, school and social justice; the organization of knowledge in disciplines as varied as possible in order to guarantee a broad education while being rooted in everyday life; the progression of knowledge construction dictated by developmental psychology and active and constructivist methods for acquiring it. The realization of these principles required a professional body of duly qualified teachers enjoying a high status, and mastering both the knowledge to be taught and psychology as the main scientific reference.

The modus operandi, based on comparative education, was much more than a simple tool for production: it was the embodiment of the IBE's actors' conceptions. The universal is constructed from the particular and the local, further enriched by the variety of practices and positions. The recognition of diversity makes it possible, through the reciprocity of points of view, to build a true understanding of reality. This understanding is at once the basis for internal solidarity and international collaboration. It implies that the institution that guarantees the reciprocity of points of view and the possible construction of the universal remains entirely neutral. But could this neutrality turn a blind eye to political practices that deny the principles of equality and the right to education?

Formerly colonized countries posed this question with insistence, calling into question the principles on which the IBE's modus operandi was based. The IBE was certainly succeeding in overcoming this crisis. But the limits of its modus operandi have been deeply questioned: the small enterprise that constituted the IBE, which operated on the basis of a highly personalized management, was struggling to manage and analyze with the appropriate tools an ever-growing mass of produced data, considering the growth of the countries that participated in the IBE's work. The depth of their divisions also revealed the difficulty of distinguishing pedagogy from politics and economics. Other institutions demonstrate this by imposing a global governance of education in which economic and political issues predominate. The testing ground that was the IBE had to be transformed: it was integrated into Unesco in 1969, which proceeded to give it new, more circumscribed tasks. And it was now subject to the usual political tensions of all international organizations. 


\section{Notes}

1. We rely primarily on the funds deposited in the IBE archives (A-BIE). This article is part of a research project funded by the Swiss national science foundation. It draws on our own contributions to the latter (Hofstetter \& Mole, 2018; Hofstetter \& Schneuwly, 2013,2020 ), including the chapters of the collective work (Hofstetter \& Ehrise, submitted): Le BIE, matrice de l'internationalisme éducatif [The IBE, a matrix of educational internationalism]. With regard to the IBE's relations with Unesco, see more particularly Brylinski (in preparation).

2. We echo the subtle title "L'Unesco oubliée" [The forgotten Unesco] de Renoliet (1999), which shows that the Institut International de Cooperation international (ICII) is a precursor of Unesco. This is true for the "c", culture, in the acronym Unesco; but the ICll didn't have its priority activities in the domain of the "e", education; Renoliet "forgets" in turn, one might say, another "precursor" of Unesco, namely the IBE, the first intergovernemental organization active in education.

3. We have explored these questions in a collective work (Droux \& Hofstetter, 2020). 4. "Code of World Aspirations to ensure respect for national particularities and in all countries the progress of national education considered as a fulfilment, under the terms of Article 26 of the Universal Declaration of Human Rights" (Rosselló, 1964, p. 5) 5. See Brylinski (in preparation) and Hofstetter \& Erhise (submitted).

6. These forums were the first international conferences that brought together representatives of government from all over the world, Many international conferences on education took place during the $19^{\text {th }}$ century; for an overview see Matasci (2015), chapter 4 Les congrès internationaux de l'enseignement: les espaces de l'échange intellectuel [The international congresses of education: the spaces of intellectual exchange].

7. List of sovereign States: https://en.wikipedia.org/wiki/List_of_sovereign_states 8. Rosselló practiced comparative education since 1933 in the Annuaires [Yearbooks] of the IBE, and since 1934 as lecturer in comparative education at the University of Geneva and theorized it in many letters and in the introductions to de yearbooks (Hofstetter, 2015). He gave more detailed elements to a theory of comparative in his doctoral thesis (1943a) Les précurseurs du Bureau international d'éducation : quelques pages inédites de l'histoire de l'éducation [The precursors of the IBE: some unpublished pages on the history of education] and in a programmatic text (1943b) Marc-Antoine Jullien de Paris : père de l'éducation comparée et précurseur du Bureau international d'éducation [Marc-Antoine Jullien de Paris : father of comparative education and precursor of the BIE]. Note that Kandel, considered as an important founder of comparative education, mentioned Jullien de Paris in a short text published in 1942; he was editor of the Educational Yearbook of Columbia from 1924 to 1944 that practiced also comparative education (Pollack, 1993) 
9. Besides this text, see also Maurel $(2006,2010)$.

10. Dorn (2006) reports on the activities of this "world's schoolmaster" in the construction of Unesco.

11. "Memorandum pour servir aux négociations entre le BIE et l'Unesco"

[Memorandum for use in negotiations between the IBE and Unesco], elaborated by the preparation committee of the IBE in July 1946. A-BIE, B35, A.1.79.1044. The IBE is even, according to Spaulding, one of Unesco's raisons d'être; for this author, it was in fact "Jean Piaget's reluctance to place the IBE directly under the responsibility of the United Nations in 1945 that favored the creation of Unesco" (Maurel, 2006, Note 7, p. 36).

12. This expression is used in the Memorandum on the relations between Unesco and IBE, written by Unesco officials. A-BIE, B35, July 1946. Rotten (1946) also considered the IBE as precursor in writing: "Es war schon die Rede davon, was für gehaltvolle Vorarbeiten und Wegweisungen für den Ausbau die neue, auf den Erdkreis ausgerichtete Organisation in ihrer Vorgängerin, dem Genfer B.I.E., findet." [We already showed the substantial preparatory work and guidance the new global organization could find for its expansion in its precursor, the Geneva B.I.E.]

13. http://dictionnaire.sensagent.leparisien.fr/list+of+sovereign+states+in+1946/en-en/ This number is of course approximative since the criteria of sovereignty may be discussed.

14. For an in-depth analysis of this, see part 2 of the book: Hofstetter \& Erhise (submitted); Boss's thesis (in preparation) highlights, among other things, the way in which the IBE Secretariat is carrying out its work to establish the IBE as a center for comparative education.

15. This does not preclude some innuendoes. In 1946, in his customary inaugural address, Piaget took a clear stand with regard to the nascent Unesco, in order to highlight the pioneering role of the IBE: "The Director [...] was delighted to see Unesco created, which has considerable resources at its disposal for the immense task which the IBE has been seeking to carry out since 1925" (p. 22). The delegate of Unesco, Wilson, for his part, acknowledged in closing that "Unesco's work will be facilitated by the IBE's experience, on which it will be able to draw" (p. 49).

16. An expression we develop in Hofstetter \& Schneuwly, 2020b.

17. Minutes of the 5th meeting of IBE Council, February 4, 1950 p. 4, B44, A_BIE. 18. We refer to Sluga and Clavin (2017); regarding ICPEs, see also Brylinski (in preparation).

19. Mention may also be made, on another level, of Unesco's opposition to Spain's participation in CIIP; or Egypt's opposition to Israel's entry into the IBE.

20. The minutes in French say "impossible", which is nonsensical.

21. The different republics of the USSR could become members of the IBE. 
22. See the chapter "L'affirmation du Tiers Monde" [The Third World's affirmation] in Maurel (2010).

23. 43 votes -the majority of African delegations, supported by Arab, Eastern

European, USSR and Indian delegations-, 7 abstentions, the other half of the countries having left the room or refused to vote (ICPE, 1964, Minutes, p. 75).

24. Letter of resignation by Piaget, December 14, 1967, quoted by E. Egger in "Le transfert du BIE à I'Unesco", Geneva, September 30, 1978. AlJJR.

\section{Bibliography}

(Manuscript sources are mentioned as notes)

Boss, C. (in preparation). Le Bureau international d'éducation (BIE), un centre mondial d'éducation comparée (1925-52): analyse du positionnement et du processus de construction (Projet de thèse). Genève: Université de Genève.

Boss, C. \& Brylinski, E. (2020) Le service d'aide intellectuelle aux prisonniers de guerre du Bureau international d'éducation (1939-1945) In J. Droux \& R. Hofstetter, (Ed.), Internationalismes éducatifs entre débats et combats (fin du $19^{\circ}$ - premier $20^{e}$ siècle). (pp. 243-276). Bern: Lang.

Brylinski, E. (in preparation). Sociogenèse d'une coopération intergouvernementale en éducation: production d'une charte universelle de l'éducation pour asseoir la paix (premier $X X^{e}$ siècle) (Projet de thèse). Genève: Université de Genève.

Dorn, Ch. (2006). 'The World's Schoolmaster': Educational Reconstruction, Grayson Kefauver, and the Founding of Unesco, 1942-1946. History of Education, 35, 297320. https://www.tandfonline.com/doi/pdf/10.1080/13504620600638299?casa_ token=b_8WFb7HKNYAAAAA:cBC9xcp8fOJSydNG2MI01ELqHmbvPBHle8yn_1sF 7IFOnpr-P5z5J2AL47IQiOb_c7KEHFQE5nAg (accessed June 20, 2020)

Droux, J. \& Hofstetter, R. (Eds.) (2020). Internationalismes éducatifs entre débats et combats (fin du $19^{e}$ - premier $20^{e}$ siècle). Berne: Lang.

Duendahl, P. (Ed.) (2016). A History of Unesco. Global Actions and Impacts. New York: Palgrave Macmillan.

Hofstetter, R. (2015). Building an "international code for public education": Behind the scenes at the International Bureau of Education (1925-1946). Prospects, 45, 31-48.

Hofstetter, R. \& ERHISE (submitted). Le BIE, une matrice de l'internationalisme éducatif. Bruxelles: Peter Lang.

Hofstetter, R. \& Mole, F. (2018). La neutralité revendiquée du BIE. Vers une Éducation nouvelle généralisée par la science piagétienne (1921-1934). In X. Riondet, R. Hofstetter \& H.-L. Go (Ed.), Les Acteurs de l'Éducation nouvelle au XX siècle (p. 195-223). Grenoble, PUG. 
Hofstetter, R. \& Schneuwly, B. (2013). The International Bureau of Education (19251968): a platform for designing a 'chart of world aspirations for education'. European Educational Research Journal, 12(2), 215-230. https://journals.sagepub. com/doi/pdf/10.2304/eerj.2013.12.2.215 (accessed June 20, 2020)

Hofstetter, R. \& Schneuwly, B. (in press, a). L'objectivité et la neutralité, ressorts de l'internationalisme éducatif? Le Bureau international d'éducation (1925-1968). Relations internationales, 183.

Hofstetter, R. \& Schneuwly, B. (in press, b). Piaget, diplomata do internacionalismo educacional. Do Bureau Internacional de Educação à Unesco (1929-1968). In R. Freitas (ed.), Circulação e internacionalização de saberes e práticas cientificas em Psicologia, Ciências Humanas e Educação - questões históricas e contemporâneas. Belo Horizonte: Centro de documentação e pesquise helena Antipoff (CDPHA). Iriye, A. (1997). Cultural Internationalism and World Order. Baltimore, London: John Hopkins University Press.

Kandel, L.L. (1942) International Coöperation in Education. (An Early Nineteenth Century Aspiration). The Educational Forum, 7, 23-29.

Laqua, D. (2011). Internationalism reconfigured: transnational ideas and movements between the world wars. New York: I. B. Tauris.

Laqua, D. (2015). The Age of Internationalism and Belgium, 1880-1930. Peace, Progress and Prestige. Manchester: Manchester University Press, 2015.

Matasci, D. (2015). L'école républicaine et l'étranger: Une histoire internationale des réformes scolaires en France. 1870-1914. Paris: Editions Ecole Normale Supérieure.

Maurel, C. (2006). L'Unesco de 1945 à 1974 (doctoral thesis). Paris: Université Panthéon-Sorbonne. https://tel.archives-ouvertes.fr/tel-00848712/file/TheseChloe Maurel.pdf (accessed June 20, 2020)

Maurel, C. (2010). Histoire de l'Unesco: les trente premières années, 1945-1974. Paris: Editions L'Harmattan.

Mylonas, D. (1976). La genèse de l'Unesco: La Conférence des Ministres Alliés de l'Éducation. Bruxelles: Bruylant.

Piaget, J. (1931/2011). The Spirit of Solidarity in Children and International Cooperation Schoo/s 8(1), 74-89. https://www.journals.uchicago.edu/doi/full/10.1086/659425 (accessed June 20, 2020)

Pollack, E. (1993). Isaac Leon Kandel. Prospects, 23 (3-4), 775-787.

Reinisch, J. (Ed.) (2016). Agents of Internationalism. Contemporary European History, 25(2), 195-205.

Renoliet, J.-J. (1999). L'Unesco oubliée: la Société des nations et la coopération intellectuelle, 1919-1946. Paris: Publications de la Sorbonne.

Rosselló, P. (1943a). Les précurseurs du Bureau international d'éducation: Quelques pages inédites de l'histoire de l'éducation. Genève: Bureau international d'éducation. 
Rosselló, P. (1943b). Marc-Antoine Jullien de Paris: Père de l'éducation comparée et précurseur du Bureau international d'éducation. Genève: Port Noir.

Rosselló, P. (1963). Difficultés inhérentes aux recherches d'éducation comparée dynamique. Revue Internationale de l'Education, 9, 203-214.

Rotten, E. (1947). Die erste Generalversammlung der UNESCO. Die Friedens-Warte, 47(1/2), 39-45.

Sluga, G. (2013). Internationalism in the Age of Nationalism. Philadelphie: Pennsylvania UP.

Sluga, G. \& Clavin, P. (Ed.) (2017). Internationalisms. A Twentieth Century history, Cambridge: Cambridge University Press.

Xypas, C. (1997). Piaget et l'éducation. Paris: PUF. 